\title{
Financial Management Strategy as a Mitigation Factor in the Acceptance of Going Concern Opinion
}

\author{
Sugeng Riyadi ${ }^{1}$, Prita Andini ${ }^{2}$, Dewi Pratiwi Yuwono ${ }^{3}$ \\ \{sugeng.riyadi@budiluhur.ac.id ${ }^{1}$, prita.andini@budiluhur.ac.id ${ }^{2}$, pratiwi.dewi@gmail.com ${ }^{3}$ \} \\ Magister of Accounting, Universitas Budi Luhur, Ciledug Raya, South Jakarta, Indonesia ${ }^{1}$, \\ Economic and Business Faculty, Universitas Budi Luhur, South Jakarta, Indonesia ${ }^{2}$, \\ Magister of Management, Universitas Budi Luhur, Ciledug Raya, South Jakarta, Indonesia ${ }^{3}$
}

\begin{abstract}
The research purpose is to test management strategy consisting of stock emission strategy, strategy to add new debt or debt restructuring, unproductive asset sale strategy and cost reduction in tackling acceptance of going concern opinion. The population are manufacturing companies which are listed on the Indonesia Stock Exchange, obtained a sample of 30 companies during the research period. Analytical tool used logistic regression. This research finds that; (i) shareholder strategy, strategy to add new debt or debt restructuring, and fixed asset strategy as a factor considered by the auditor in giving a going concern audit opinion (ii) reduction / cost efficiency strategy not as an auditor's consideration in giving a going concern opinion (iii) financialbased control variables into consideration of the Auditor in providing a going concern opinion.
\end{abstract}

Keywords: Financial management strategy factors, mitigation, going concern opinion.

\section{Introduction}

The independent auditor opinion is avoided by management is opinion with going concern. If Auditor finds material uncertainty to entity ability to maintain its business continuity, Auditor will give going concern audit opinion. During the last 5 years, companies that accept going concern opinion have decreased by $21 \%$, but there are still companies that accept the going concern opinion as many as 13 companies from 30 manufacturing companies in Indonesia. Spathis (2003) and Gaganis (2007) state that, the ratio of profitability ratios is estimated to be proportional to the fair opinion without the exception of the auditor [1] indicates that the ratio has an important contribution to the auditor's opinion, while the receivable income ratio and the receivable/inventory ratio have little impact on the auditor's opinion decision [3]. States that one of the ranking methods related to the concept of going concern is to apply financial ratios through a combined form. These statements show that financial variables are important variables that auditors consider in providing a going concern opinion [4]. Tested the going concern opinion with information available to the public, the results of his research concluded. First, firms that in the previous year received unqualified views, are likely to receive similar opinion decisions for the current year. Second, firms with high financial leverage are less likely to accept unqualified opinion decisions. Third, firms 
with higher after-tax earnings tend to receive unqualified opinion decisions. The results of this research show that published financial variables can be used to predict the survival of a company. This research will test the financial strategy in tackling going concern opinion. The financial strategy in question is; emission of new shares, debt restructuring, selling of nonproductive assets, and cost reduction strategies. The use of these financial strategy variables distinguishes this research with others [1],[2],[4]. The financial variables used in this researcher as control variables. The difference of this research with other research is the use of variable financial strategy consisting of emission of new shares, debt restructuring, selling of non-productive assets, and cost reduction strategies and variable financial ratios as variable control.

\subsection{Business Continuity Theory}

The business continuity theory is assumed that the business entity will operate continuously to continue its commitment or activity indefinitely Ahmed Riahi (2004) and Kuruppu, Laswad, \& Oyelere (2003) state that business continuity is a concept which assumes that the reporting entity will continue to operate in the future, and will be able to realize financial assets and liabilities under normal circumstances [5],[6]. With these two notions of going concern it shows that the reporting entity's financial statements provide information about the financial condition as part of the ongoing financial report. Business survival is always associated with the management capability in managing the company to survive. When companies experience financial problems (financial distress), corporate operations will be disrupted. This research is using the theory of survival as a grand theory based on the general view that established entities must be maintained its survival.

\subsection{Audit Going Concern Opinion}

A going concern audit opinion can be interpreted as an opinion given by the auditor to ascertain whether the company can maintain its survival IAI (2007) Information concerning going concern audit opinion for the users of financial statements as material to make decisions in investing [7]. Investors expect the auditor to provide timely and objective information about the company's financial condition. This timely and objective information is consistent with the signaling theory, which states that the company should promptly provide information to users of financial statements in good or bad circumstances. Constantinides (2002) analyzed the influence of going concern opinion toward three groups of actors each of the auditors, bankers and practitioners, the results of the analysis concluded that there are differences in behavior in response to going concern [8]. The results of this analysis reinforce the importance of going concern information for the perpetrators. Geiger, Raghunandan, \& Rama (2005) documented that the increase in going concern modification rates in bankrupt companies after December 2001 was due to changes in auditor decisions. This analysis results corroborated the importance of going concern information for perpetrators [9].

\subsection{Stock Emission Strategy}

The management of stock's emission strategy is an effort to maintain the company's survival and can improve the management credibility that auditor can consider when making a going concern opinion decision. [10] views the stock issuance strategy would be effective in 
overcoming financial difficulties if the minimum share emission amount is 5\%. [11] states that the determinants of going concern (GCO) opinions include client factors, auditor factors, auditor-client relationships, and other environmental factors. Especially the client factor is related to various strategies undertaken by the client in maintaining the viability of the company, such as the emission of new shares. Thus the strategy of share emissions by management can serve as a mitigation factor in the acceptance of going concern opinion. Based on the explanation, hypothesis 1 "new stock emission becomes the factor that the auditor considers when it will give a going concern audit opinion"

\subsection{Debt Withdrawal Strategies}

The Companies experiencing financial distress indicated by the existence of negative working capital can be overcome by attracting long-term debt [10],[11],[12]. States that the determinants of going concern (GCO) opinions include client factors, auditor factors, auditorclient relationships, and other environmental factors. Especially the client factor is related to various strategies undertaken by the client in maintaining the viability of the company, such as debt restructuring / attract new debts. With the drawdown of long-term debt can be used either to finance the company's operations, the settlement of short-term liabilities as well as the operational needs of the company. Thus, the management strategy to increase lending can serve as a mitigation factor in the acceptance of going concern opinion. Thus hypothesis 2 : "the withdrawal of new debt becomes a factor considered by the auditor at the time of giving a going concern audit opinion".

\subsection{Reduction pf Unproductive Asset}

One of the management strategies undertaken to restore the state of a company experiencing financial distress is by reducing the non-productive assets next sell it [14] proved that companies experiencing financial distress conditions can recover their condition by restructuring their assets in the form of an asset divestment. [11] states that the determinants of going concern (GCO) opinions include client factors, auditor factors, auditor-client relationships, and other environmental factors. Especially the client factor is related to various strategies undertaken by the client in maintaining the viability of the company, such as selling assets that are not productive. Thus, management strategy to sell non-productive assets can serve as a mitigation factor in the acceptance of going concern opinion. Based on the above explanation hypothesis 3: "selling unproductive assets into auditor considerations in providing going concern audit opinion".

\subsection{Cost Efficiency Strategy}

Companies experiencing financial distress with indication of occurrence; working capital with negative cost, deficit, operating loss, and net loss. These conditions encourage managers to implement strategies to avoid receiving going-concern opinions by reducing costs, as this strategy is one of the turnaround strategies that can improve the condition of financial distress [15]. Carson et al., (2013) states that the determinants of going concern (GCO) opinions include client factors, auditor factors, auditor-client relationships, and other environmental factors [11]. Especially the client factor is related to various strategies undertaken by the client in maintaining the viability of the company, such as cost reduction strategies. Thus management strategies to reduce costs can serve as a mitigation factor in the acceptance of 
going concern opinion. Based on the description of the proposed hypothesis H4: Cost efficiency strategy affect the acceptance of going concern opinion.

\section{Research Methodology}

The research population is a manufacturing company listed on the Indonesia Stock Exchange from 2010 to 2015. Sampling technique by purposive sampling method, with the following criteria (i) the company's complete financial report. (ii). the financial statements have been audited (iii) the company has financial distress problems, at least 1 criterion indicated one of the conditions of the following conditions (1) negative working capital, (2) deficit cash balance, and (3) net income. The sample of the research are 30 companies during 6 years and total data are 180 data sample. This research uses logistic regression analysis tools, because the dependent variable of the nominal or dummy variable, the model equation. as follows [16]:

$$
\begin{aligned}
G C=\frac{\operatorname{Ln} O G C}{1-O G C}= & \beta_{0}+\beta_{1} S-E q u i t y+\beta_{2} S-\text { Debt }+\beta_{3} S-\text { Asset }+\beta_{4} S-\text { Cost } \\
& +\beta_{5} C A C L+\beta_{6} L T D T A+\beta_{7} N I B T S+\beta_{8} D E R+\beta_{9} R O A+e
\end{aligned}
$$

$\beta_{-}(0)=$ Constants

$\beta_{-}(1)-\beta_{-}(9)=$ Coefficient

OGC $=$ Going Concern Opinion $(1$ if opinion

$\mathrm{GC}$ and 0 if non GC opinion)

S-Capital $=$ Management strategy to increase

capital ( 1 if there is a plan or action and 0 if not or $<5 \%$ )

S-Debt = Management strategy to attract debt, ( 1 if there is a plan or action and 0 if not $)$

S-Assets = Management strategy to sell unproductive assets, (1 if there is a plan or action and 0 if not)

S-Cost $=$ Management strategy to reduce expenditure $(1$ if there is a plan or action and 0 if not)

CACL $=$ Current assets divided by current liabilities

LTDTA $=$ Long-term debt divided by total assets

DER $=$ Total debt divided by equity or capital

NIBTS $=$ Net income before tax divided by total sales

ROA = Earnings before interest and tax or Earnings Before interest and tax divided by total assets

$\mathrm{e}=$ Error or switcher

\section{Discussion}

The result of Hosmer Lemeshow's fit model test is that Chi-Square is 7,991 with df 8 and significance level is 0,434 . Level significance is greater than 0.05 which means that the model 
is able to predict the value of observations or it can be said that this research model is a model that is fit. The result of statistic test $-2 \log$ Likelihood indicates that there is a decrease of $\log$ Likelihood value between block 0 and block 1 , indicating that adding variable makes model better.

\subsection{New Share Emissions Become Factors to Consider the Auditor At Will Give Audit Going Concern Opinion"}

The test results show that the new share issuance strategy becomes the consideration of the Auditor when it will give the opinion of going concern. Wald value is 5,872 and the significance level is $0,015<0,05$. This result is consistent with the statement of Behn, B K., Kaplan, E.S., Krunwiede, K.R(2001) views the stock issuance strategy will be effective in overcoming financial difficulties if the amount of stock issuance is at least 5\% [10]. Consistent with the results of research Sudarsanam, (2001)which proves that companies experiencing financial distress will recover the financial difficulties by performing an equity-based strategy. Carson et al., (2013)states that the determinants of going concern (GCO) opinions include client factors, auditor factors, auditor-client relationships, and other environmental factors. Especially the client factor is related to various strategies undertaken by the client in maintaining the company's survival, such as new share emissions. Thus, a minimum share emission strategy of $5 \%$ of the total outstanding shares shall be considered by the auditor in giving a going concern opinion.

\subsection{Withdrawal of New Debt Become Factor Considered by Auditor When Will Give Audit Going Concern Opinion}

Wald value of 7.704 and significance level of $0.006<0.05$. The results of this research are in accordance with the classification presented by Carson et al., (2013)states that the determinants of going-concern opinion (GCO) include client factors, auditor factors, auditorclient relationships, and other environmental factors. Especially the client factor is related to various strategies undertaken by the client in maintaining the viability of the company such as debt restructuring. A company experiencing financial distress is shown by the existence of negative working capital can be overcome by attracting long-term debt. Thus debt restructuring or attracting new debt, which is used in accordance with the predetermined plan will improve the performance of the company ultimately Auditors will consider to provide a going concern opinion [10],[12],[13].

\subsection{Selling Unproductive Assets into Auditor's Considerations in Giving Opinion of Going Concern Audit}

Strategies to reduce / sell unproductive assets into independent auditors' consideration at the time will provide a going concern opinion. Wald value of 6.840 and significance level of $009<0.05$. The results of this research in accordance with the research Sudarsanam,(2001) to prove that companies experiencing financial distress conditions can recover conditions by restructuring assets in the form of assets divestment. Carson et al., (2013)states that the determinants of going concern (GCO) opinions include client factors, auditor factors, auditorclient relationships, and other environmental factors. Especially the client factor is related to various strategies undertaken by the client in maintaining the viability of the company, such as 
selling assets that are not productive. These results indicate that the assets must be managed professionally in maintaining the viability of the company.

\subsection{Cost Efficiency Strategy Has No Effect on Acceptance of Going Concern Opinion.}

The cost efficiency strategy has no effect on the independent auditor at the time of giving a going concern opinion. Wald value is 0.012 and significance level is $0,912>0,05$. The results of this research are not in accordance with Pearce II, John A., Robinson, Richard B (2003) which states, encouraging managers to implement cost reduction strategies / cost efficiency in order to avoid acceptance of going concern opinion because this strategy is one of turn around strategies that can improve the condition of financial distress. And Carson et al., (2013) states that the determinants of going-concern opinions (GCO) include client factors, auditor factors, auditor-client relationships, and other environmental factors. Especially the client factor is related to various strategies undertaken by the client in maintaining the viability of the company, such as cost reduction strategies.

\section{Conclusion}

This research obtains information relating to management effort of company to overcome going concern audit opinion from independent auditor as follows; First the company's management in running the business must implement a cost efficiency strategy. Secondly in terms of tackling the acceptance of a going concern audit opinion, the first option is the stock issuance strategy, the second reduces the unproductive assets, and the third withdraws or restructures the debt. Last, although the strategy of cost efficiency has no effect on going concern opinion, where management must still manage efficiently, effectively and economically.

\section{References}

[1]C. T. Spathis, "Audit Qualification, Firm Litigation, and Financial Information: an Empirical Analysis in Greece,” Int. J. Audit., vol. 7, no. 1, pp. 71-85, 2003.

[2]S. C. and Z. C. Gaganis C, Pasiouras F, "A Comparasion Of Nearest Neighbours, Discriminant And Logit Models For Auditing Decisions," Intell. Syst. Accounting, Financ. Manag., vol. 15, no. 12, pp. 23-40, 2007.

[3]S. Mahdi and R. Vahab, "Relationship between Going Concern Concept and P / E Ratio in Emerging Market : Case of Iran," vol. 1, no. 1, pp. 1-21, 2009.

[4]T. T. Ha, T. Anh, T. Nguyen, and T. T. Nguyen, "FACTORS INFLUENCING THE AUDITOR" S GOING - CONCERN OPINION DECISION Thuy Thi Ha - Truc Anh Thi Nguyen - Trieu Thi Nguyen," pp. 1857-1870, 2016.

[5]B. Ahmed Riahi, Accounting Theory 5 edition. Thomson Learning (a division of Thomson Asia Pte Ltd.), 2004.

[6]N. Kuruppu, F. Laswad, and P. Oyelere, "The efficacy of liquidation and bankruptcy prediction models for assessing going concern,” Manag. Audit. J., vol. 18, no. 6/7, pp. 577-590, 2003.

[7]I. A. I. (IAI), Standar Profesional Akuntan Publik (SPAP). Salemba Empat, 2007.

[8]S. Constantinides, “Auditors', Bankers' And Insolvency Practitioners' 'Going-Concern' Opinion Logit Model,” Manag. Audit. J., vol. 17, no. 8, pp. 487-501, 2002.

[9]M. A. Geiger, K. Raghunandan, and D. V. Rama, "Recent changes in the association between bankruptcies and prior audit opinions," Auditing, vol. 24, no. 1, pp. 21-35, 2005. 
[10]K. . Behn, B K., Kaplan,E.S and Krunwiede, "Further Evidence on the Auditor's Going-Concern Report: The Influence of Management Plans," Audit. J. Pract. Theory, vol. 20, no. 1, pp. 13-28, 2001. [11]E. Carson, N. L. Fargher, M. A. Geiger, C. S. Lennox, K. Raghunandan, and M. Willekens, "Audit reporting for going-concern uncertainty: A research synthesis," Auditing, vol. 32, no. SUPPL.1, pp. 353-384, 2013.

[12]W. McKeown, J.C., Mutchler, F.J. dan Hopwood, “Towards An Explanation Of Auditor Failure To Modify The Audit Opinion Of Bankrupt Companies,” Audit. A J. Pract. Theory, vol. 10, p. Supplement: 1-17, 1991.

[13]L. Bruynseels, M. Willekens, and M. Willekens, "Strategic Viability and Going-Concern Audit Opinions Strategic Viability and Going-Concern Audit Opinions," 2006.

[14]J. L. Sudarsanam, "Corporate Financial Distress and Turnaround Strategies: n Empirical Analysis,” Br. J. Manag., vol. 12, no. 3, pp. 183-189, 2001.

[15]A. . dan R. . Pearce II., Robinson, Strategic Management: Formulation, Implementation and Control, 8th ed. New York: Graw -Hill Companies, Inc, 2003.

[16]I. Ghozali, Analisis Multivariate Lanjutan dengan Program SPSS. Third Edition. Badan Penerbit Universitas Diponegoro Semarang, 2006. 